\title{
Risperidone and Hepatotoxicity in Children and Adolescent: A Literature Review
}

\author{
Mazlum ÇÖPÜR ${ }^{1}$, Sidar ÇÖPÜR ${ }^{2}$
}

\begin{abstract}
Risperidone is a second generation anti-psychotic drug that is commonly preferred in the treatment of schizophrenia, attention deficit hyperactivity disorder and bipolar disorders. Risperidone-associated hepatic adverse effects have long been investigated and continues to be unclear. In this review, our aim is to establish the possible hepatic adverse effects linked to risperidone treatment in children and adolescent in terms of severities and reversibility. We performed literature search via electronic databases (PubMed, Embase and the Cochrane Library) in August 2019. Risperidone treatment may lead to alterations in liver function test (LFT), mostly asymptomatic and reversible with the discontinuation or normalizes with time. Furthermore, there are few cases reporting risperidone-induced cholestatic hepatitis and immunoallergic hepatitis. Although exact mechanism of action of risperidone on liver remains unknown, there are growing evidences that link alterations of fatty acid biosynthesis to hepatic adverse effects. We recommend physicians to take basal LFT prior to risperidone treatment and monitor LFT during treatment. Additionally, physicians should be aware that most alterations at LFT associated with risperidone use are asymptomatic and reversible. However, more comprehensive studies investigating risperidone-associated hepatic adverse effects should be performed to reach a definitive outcome.
\end{abstract}

Key Words: Risperidone; liver function tests; reversibility; antipsychotic agents; adverse effect.

\section{Çocuk ve Ergenlerde Risperidon Kullanımı ile Karaciğer Toksisitesi: Literatür}

\section{Taraması}

Özet: Risperidon; şizofreni, dikkat eksikliği hiperaktivite bozukluğu ve bipolar bozukluğun tedavisinde yaygın olarak tercih edilen ikinci kuşak anti-psikotik bir ilaçtır. Çocuklarda risperidon kullanımının karaciğer üzerine olası yan etkileri uzun yıllardır incelenmekte olup konuyla ilgili kesin bir sonuca varılamamıştır. Bu çalışmada, çocuk ve ergenlerde risperidon kullanımının olası yan etkilerini şiddet ve geri dönüşümlülüğü dahil olmak üzere birçok açıdan incelemeyi amaçlamaktayız. Konu, ağustos 2019 tarihi itibariyle yayınlanmış olan çalışmalar arasından PubMed, Embase ve Cochrane Library olmak üzere üç elektronik veri tabanında araştırılmıştır. Risperidon kullanımının karaciğer fonksiyon testlerinde (KFT) bozukluklara yol açabilmesine rağmen bu değişimlerin çoğunlukla ilacın bırakılmasını takiben geri dönüşümlü olduğu ve klinik bir belirtiye yol açmadığı görülmüştür. Aynı zamanda, risperidon kullanımının immüno-alerjik hepatit ve kolestatik hepatit ile ilişkili olabileceğini gösteren birtakım vaka bildirimleri literatürde mevcuttur. Risperidonun karaciğer hasarına yol açan temel etki mekanizması henüz bilinmiyor olsa da KFT'deki bozuklukların yağ aside sentezindeki değişiklikler ile ilişkili olduğu görüşü hakimdir. Konuyla ilişkin kesin bir kanıya varmadan önce daha kapsamlı çalışmalara ihtiyaç duyulmakla birlikte, risperidon tedavisi düşünülen hastalarda tedavi öncesi bazal bir KFT yapılıp tedavi boyunca değerlerin takip edilmesinin faydalı olacağı görülmektedir. Testlerde meydana gelebilecek değişimlerin çoğu zaman asemptomatik ve geri dönüşümlü olduğu ve karaciğer yetmezliğine yol açmayacağı bilinmelidir.

Anahtar Kelimeler: Risperidon; karaciğer fonksiyon testi; anti-psikotik ilaç; yan etki.

\footnotetext{
${ }^{1}$ Professor of Child and Adolescent Psychiatry, Arel University Department of Psychology, İstanbul-Türkiye.

${ }^{2}$ Koç University School of Medicine, İstanbul-Türkiye.

Address of Correspondence / Yazışma Adresi: Prof. Dr. Mazlum Çöpür, Arel University Department of Psychology, İstanbul-Türkiye. Email: sidar1996@yahoo.com.tr
}

Date of Received/Geliş Tarihi: 27.09.2019, Date of Revision/Düzeltme Tarihi: 08.01.2020, Date of Acceptance/Kabul Tarihi: 10.01 .2020

Citing/ Referans Gösterimi: Çöpür, M., Çöpür, S. (2020). Risperidone and Hepatotoxicity in Children and Adolescent: A Literature Review. Kıbrls Türk Psikiyatri ve Psikoloji Dergisi, 2(1): 54-58 doi:10.35365/ctjpp.20.2.8 


\section{Introduction}

Risperidone whose exact mechanism of action is unknown but thought to be related to the inhibition of dopaminergic D2 and serotonergic 5-HT2A receptors is a second generation anti-psychotic drug used in the treatment of many psychiatric conditions including attention deficit hyperactivity disorder (ADHD), childhood autism, mood disorders, Tourette's disorder and childhood psychosis (Cohen, 1994; Turgay, 2002; Findling, 2000). There is an age limitation for risperidone treatment varying with the diagnosis. Since there are not adequate investigations regarding the efficiency and adverse effects of risperidone treatment in children and adolescent, usage of risperidone is not preferred in autism patients under age 5, bipolar disorder patients under age 10 and schizophrenia patients under age 13 (Cohen, 1994; Turgay, 2002; Findling, 2000). Common side effects include headache, weight gain, fatigue, shivering and depressive mode, whereas, adverse effects related to liver remain unknown (Cohen, 1994; Turgay, 2002; Findling, 2000; Uchida, 2009). In addition to that, studies investigating the adverse effects of risperidone treatment in children and adolescent are few in number and mostly non-comprehensive, thus, side effects of risperidone treatment in children and adolescent remain unknown

Liver damage caused by anti-psychotic drugs are thought to be mediated via three different mechanisms (TellesCorreia, Barbosa \& Cortez-Pinto, 2017). First, metabolites formed by the metabolism of anti-psychotic drugs in liver such as acetaminophen-S-protein may accumulate at hepatocytes and lead to toxicity (TellesCorreia, 2017). Second, anti-psychotic drugs may lead to non-alcoholic fatty liver disorder or metabolic syndrome by impairing liver function (Telles-Correia, 2017). Third, few anti-psychotic drugs may lead to liver damage by impairing bile transport such as chlorpromazine (TellesCorreia, 2017). Drug-induced liver injury can be evaluated via liver function tests including serum alanine transaminase (ALT), alkaline phosphatase (ALP), aspartate transaminase (AST) and bilirubin levels. However, current investigations are unable to determine the exact mechanism of action for risperidone.

Effects of atypical anti-psychotics via dopaminergicserotonergic system, possible adverse reactions and efficiency in the treatment of psychiatric disorders have been thoroughly examined in adult population (McCracken, 2002; Snyder, 2002). Promising outcomes lead to increasingly common utilization in pediatric population, whereas, studies in this age group are limited (McCracken, 2002; Snyder, 2002). Furthermore, deteriorating effects of first generation anti-psychotic drugs on liver function have been well established and there are increasingly strong evidences indicating similar outcomes with atypical anti-psychotic drugs including risperidone. In this literature review, we aim to investigate the possible hepatotoxic effects of risperidone treatment mainly at pediatric age group.

\section{Method}

We have searched our area of interest from three different databases (PubMed, Embase and Cochrane) by using Medical Subject Headings (MeSH) terms including "risperidone", "liver function test", "liver", "adolescent" and "adverse effects" by June 2019. The studies found on the literature search have been assessed and analyzed by the two authors independently. Inclusion criteria for the literature review include studies investigating the relationship between risperidone treatment and liver injury in children and adolescents, being published in a peer-reviewed journal between 1995 and 2019 in English. We have found 27 studies fitting our inclusion criteria.

\section{Results}

Even though there are many studies investigating the effects of risperidone on liver injury, there are controversial outcomes. In addition to human studies there are few studies investigating this issue on rats and mice. A study conducted with 100 patients, ages varying between 3 and 18, reveals that risperidone treatment for 6-12 months leads to elevation of serum alanine transaminase (ALT), aspartate transaminase (AST), alkaline phosphatase (ALP) and bilirubin levels (Karaman, 2011). In addition, no signs of jaundice or liver failure or any type of clinical symptom have been observed while discontinuation of risperidone treatment is accompanied with the normalization of serum levels (Karaman , 2011). In another study conducted with 102 patients, we observe reversible elevation of serum bilirubin and alkaline phosphatase (ALP) levels without any sign of liver failure as a result of risperidone treatment for 6 months (Erdoğan, 2010). Another study conducted with 120 patients (Age 3 to 17) demonstrates that risperidone treatment results in weight gain in $57.4 \%$ of participants and asymptomatic deterioration of liver function tests and serum bilirubin levels (Erdoğan, 2008). Additionally, there are 2 case reports in the literature illustrating transient increases in liver function tests as a result of risperidone treatment (Whitworth, Liensberger \& Fleischhacker; 1999).

A research investigating the metabolic effects of risperidone treatment with 124 autistic patient concludes that 24-week risperidone treatment leads to statistically significant weight gain and related metabolic alterations (Elevation of serum levels of HbA1c, glucose, ALT and leptin) compared to the control group (Scahill, 2016). On the other hand, another study investigating the effects of second generation anti-psychotic drugs over a year shows that there is no statistically significant elevation of liver enzymes or any clinical symptom (Baeza, 2018). Similar study conducted with 312 patients on second generation anti-psychotic drugs reports that asymptomatic deterioration of liver function tests and elevation of bilirubin levels are seen in the first month of treatment which mostly normalizes in 6 months without any intervention (Atasoy, 2007). Moreover, a study conducted with 23 patients reveals that cytolytic hepatitis develops in response to risperidone usage (MouradianStamatiadis, Dumortier, Januel, Delmas \& Cabaret, 2002).

In addition to more comprehensive research papers there are many case reports emphasizing upon the same issue. Development of liver injury has been reported on a 19year-old patient following 3 weeks of risperidone treatment (López-Torres , 2014). Another case report demonstrates weight gain and steatohepatitis in a 17year-old female (Holtmann, 2004). In addition, another case report illustrates the emergence of peripheral edema in 80-year-old female patient using risperidone due to major depression which may be associated with liver 
damage since it is accompanied with elevated liver enzymes and recovers after discontinuation (Hosseini \& Ahmadi, 2012).

A case series performed on 13 pediatric age group patients reveals that risperidone treatment leads to obesity, deterioration of liver function tests and increase in steatohepatitis in 2 patients, all of which are reversible with the discontinuation of therapy (Kumra, Herion, Jacobsen \& Briguglia, 2007). A controversial result has been reported by a study conducted with 38 patients using on average $2.5 \mathrm{mg}$ daily risperidon for 15 months without any deterioration in liver function tests (Szigethy, 1999).

Another issues that require additional attention regarding the effects of risperidone on liver are immunoallergic hepatitis and cholestatic hepatitis. Even though there are no comprehensive study in the literature investigating these effects, there are unique case reports indicating that risperidon may be responsible from those outcomes (Krebs, 2001; Wright \& Vanderberg, 2001; Codeiro \& Elkis, 2007; Esposito, 2005; Francisca, 2005).

Among the studies investigating the molecular background of the effects of risperidone on mice liver, we observe that risperidone treatment results in hyperglycemic state, increase in visceral adipose tissue and increase in the fat content of liver confirmed by MRI studies (Auger, 2014). Furthermore, analysis of adipose tissue content reveals that decrease in the percentage of multiple unsaturated fatty acids (Auger, 2014). These metabolic alterations are thought to be related to increase in the production of steroyl-coenzyme A enzyme at the transcription level (McNamara, 2011). In addition to effects of the enzyme on fatty acid amount and balance it may alter serum insulin levels. Supporting evidence is derived from the study that demonstrates higher degree of liver injury in experimental mice with omega-3 fatty acid deficiency in response to risperidone treatment (McNamara, Magrisso, Hofacer \& Jandacek, 2012). Moreover, mice that have received resveratrol in addition to risperidone treatment suffer from milder degrees of liver injury (Azirak, 2019). Another study performed on rats shows that coenzyme Q10 and $\mathrm{N}$-acetyl cysteine have protective effects against liver injury in rats using risperidone and suggests that effects of risperidone on liver may be mediated via mitochondrial and lysosomal injury (Eftekhari, 2016; Horska, 2017). On the other hand, metabolic alterations observed in rats and mice are not directly correlated with the degree of weight gain. Moreover, there is no significant alteration in the number and histological structure of hepatocytes after short or long term risperidone treatment (Halıc1, Keleş \& Kaplan, 2008).

\section{Discussion}

We have found that risperidone treatment in children and adolescent used in the treatment of many psychiatric conditions including ADHD, Tourette's disorder and mood disorders may result in deterioration of liver function tests and liver injury most of which are not associated with any clinical symptoms and are reversible with the discontinuation of therapy. However, it is important to recognize the fact that studies related to this issue are in general short term studies, thus, need for more comprehensive and long term studies is critical. As a result of our literature review, we have concluded that risperidone-induced liver injury may arise as a result of both direct hepatocyte injury and cholestatic injury.

Investigations regarding the mechanism of action underlying the hepatic adverse effects of risperidone treatment are few in number and not very comprehensive. In vivo and in vitro studies result in possible hypothesis including accumulation of reactive oxygen species (ROS), increase in the permeability of lysosomal membrane, deficiency of glutathione and loss of electrochemical potential in mitochondria. Current evidence indicates possible relation between the deterioration of liver function tests and alterations of fatty acid synthesis in terms of quantity and quality. These evidences include worsening of hepatic adverse effects in animals with omega-3 fatty acid deficiency and improvement of condition in animal subjects using resveratrol in conjunct with risperidone. The theory with the highest validity about risperidone-associated hepatic adverse effects and hepatosteatosis includes risperidoneinduced increase in the activity of at stearoyl-CoA desaturase, an enzyme converting stearic acid (18:0) into oleic acid (18:1) by formation of double bond in the expense of NADPH. Altered enzymatic activity results in increased plasma oleic/stearic acid ratio and imbalance at fatty acid metabolism results in increased plasma fatty acids and glucose level. In addition, altered intracytoplasmic NADPH/ $\mathrm{NADP}^{+}$ratio leads to high degrees of oxidative stress in hepatocytes. Supporting evidences include reduced rates of risperidone-induced hepatosteatosis when anti-oxidant molecules such as Nacetylcysteine or coenzyme Q10 is co-administered with risperidone while augmentation of hepatic adverse effects in subjects with omega-3 deficiency (McNamara, Magrisso, Hofacer \& Jandacek, 2012; Eftekhari, 2016). However, supporting evidence for other hypothesis are also present and sufficient trials with human subject are lacking. Thus, the need for further and more comprehensive studies investigating the mechanism of action of risperidone-induced liver injury is obvious.

Even though efficiency and adverse effects of risperidone treatment are more thoroughly examined in adult population, promising efficiency rates have also been observed in the pediatric population. In addition, most of risperidone-induced liver injury cases are asymptomatic and do not progress into liver failure while being reversible with discontinuation of therapy. Therefore, we recommend to obtain basal liver function tests in patients who are candidate for risperidone therapy and follow-up of liver enzymes throughout the treatment (Çöpür \& Erdoğan, 2011).

Conflict of Interest: The authors declare that they have no conflict of interest.

Funding: No sources of funding are received for this study. 


\section{References}

Atasoy, N., Erdogan, A., Yalug, I., Öztürk, Ü., Konuk, N., Atik, L. (2007). A review of liver function tests during treatment with atypical antipsychotic drugs: A chart review study. Progress in Neuro-Psychopharmacology \& Biological Psychiatry, 31(6), 1255- 60 .

Auger, F., Patrick, D., Françoise, M., Nizard, M.F., Durieux, N., Bordet, R. (2014). Long-term risperidone treatment induces visceral adiposity associated with hepatic steatosis in mice: A magnetic resonance approach. Schizophrenia Research and Treatment, 11

Azirak, S., Bilgic, S., Tastemir, K., Güvenç, A.N., Kocaman, N., Özer, M.K. (2019). The protective effect of resveratrol against risperidone-induced liver damage through an action on fas gene expression. General Physiology and Biophysics, 38(3), 215-225.

Baeza, I., Serna, E., Calvo-Escalona, R., Naranjo, M.J., Latorre, R.P., Martinenz-Cantarero, C.M. (2018). One-year prospective study of liver function tests in children and adolescents on second-generation antipsychotics: Is there a link with metabolic syndrome? Journal of Child and Adolescent Psychopharmacology, 28(7), 463-73.

Cohen, L.J. (1994). Risperidone. The Journal of Human Pharmacology and Drug Therapy,14(3), 253-265.

Copur, M., Erdogan, A. (2011). Risperidone rechallenge for marked liver function test abnormalities in an autistic child. Recent Patents on Endocrine, Metabolic \& Immune Drug Discovery, 5(3), 237-239.

Cordeiro, Q., Elkis, H. (2007). Pancreatitis and cholestatic hepatitis induced by risperidone. Journal of Clinical Psychopharmacology, 21(5), 529-30.

Eftekhari, A., Ahmad-Durieuxsian, E., Azarmi, Y., Parvizpur, A., Hamishehkar, H., Eghbal, M.A. (2016). In vitro/vivo studies towards mechanisms of risperidone-induced oxidative stress and the protective role of coenzyme q10 and nacetylcysteine. Toxicology Mechanisms and Methods, 26(7), 520-528

Erdogan, A., Atasoy, N., Akkurt, H., Öztürk, D., Karaahmet, E., Yaluğ İ. (2008). Risperidone and liver function tests in children and adolescents: A short-term prospective study. Progress in Neuro-Psychopharmacology \& Biological Psychiatry, 32(3), 849-57.

Erdogan, A., Karaman, M., Ozdemir, E., Yurteri, N., Tufan, E.A., Turcer, A.M. (2010). Six months of treatment with risperidone may be associated with nonsignificant abnormalities of liver function tests in children and adolescents: A longitudinal, observational study from turkey. Journal of Child and Adolescent Psychopharmacology, 20(5), 407-13.

Esposito, D., Brocvielle, H., Becquemont, L., Hardy, P., Chouinard, G., Corruble, E. (2005). Risperidone-induced immune allergic hepatitis. American Journal of Psychiatry, 162(10), 1984.

Findling, R.L., McNamara, N.K., Branicky, L.A., Schluchter, M. D., Lemon, E., Blumer J.L. (2000). A double-blind pilot study of risperidone in the treatment of conduct disorder. Journal of American Academy of Child and Adolescent Psychiatry, 39(4), 509-516

Francisca, L., Carmen, H., Nuria, B., Ros, B.N. (2005). Acute cholestatic hepatitis probably associated with risperidone. The International

Journal of Psychiatry in Medicine, 35(2), 199-205.

Halıcı, Z., Keleș, O., Kaplan, S. (2008). Chronically Administered Risperidone Did Not Change the Number of Hepatocytes in Rats: A Stereological and Histopathological Study. Basic \& Clinical Pharmacology \& Toxicology, 102(5), 426-32.
Holtmann, M., Kopf, D., Mayer, M., Behtinger, E., Schmidt, H.M. (2004). Risperidone-associated steatohepatitis and excessive weight-gain. Pharmacopsychiatry, 36(5), 206-7.

Horska, K., Ruda-Kucerova, J., Karpisek, M., Suchy, M., Opatrilova, R., Kotolova, H. (2017). Depot risperidone-induced adverse metabolic alterations in female rats. Journal of Psychopharmacology, 31(4), 487-499.

Hosseini, S., Ahmadi, A. (2012). Peripheral edema occurring during treatment with risperidone combined with citalopram. Case Reports in Medicine, 540732

Karaman, M., Erdogan, A., Tufan, E., Yurteri, N., Özdemir, E., Ankaralı, H. (2011). Liver function tests in children and adolescents receiving risperidone treatment for a year: A longitudinal, observational study from Turkey. International Journal of Psychiatry in Clinical Practice, 15(3), 204-8.

Krebs, S., Dormann, H., Muth-Selbach, U., Selkchard, H., Kay, B., Thomas, H.C. Risperidone-induced cholestatic hepatitis. European Journal of Gastroenterology and Hepatology, 2001; 13(1): 67-9.

Kumra, S., Herion, D., Jacobsen, L., Briguglia, C. (1997). Risperidone-induced hepatotoxicity in pediatric patients. Journal of the American Academy of Child and Adolescent Psychiatry, 36(5), 701-5.

López-Torres, E., Süveges, A., Peñas-Ledó, E., Dona, A., Dorado, P., Lerenna, L.A. (2014). Liver enzyme abnormalities during antipsychotic treatment: A case report of risperidoneassociated hepatotoxicity. Drug Metabolism and Drug Interactions, 29(2), 123-6.

McCracken, J.T., McGough, J., Shah, B., Cronin, P., Hong, D., Aman, M.G. (2002). Risperidone in children with autism and serious behavioral problems. New England Journal of Medicine, 347, 314-21.

McNamara, R., Jandacek, R., Rider, T., Tso, P., Cole-Strauss, A., Lipton, W.J. (2011). Atypical antipsychotic medications increase postprandial triglyceride and glucose levels in male rats: Relationship with stearoyl-coa desaturase activity. Schizophrenia Research, 129(1), 66-73.

McNamara, R., Magrisso, I., Hofacer, R., Jandacek, R. (2012). Omega-3 fatty acid deficiency augments risperidone-induced hepatic steatosis in rats: Positive association with stearoyl-coa desaturase. Pharmacology Research, 66(4), 283-91.

Mouradian-Stamatiadis, L., Dumortier, G., Januel, D., Delmas, A.B., Cabaret, W. (2002). Liver function tests during treatment with antipsychotic drugs: A case series of 23 patients. Progress in Neuro-Psychopharmacology \& Biological Psychiatry, 26(7), 1409-11.

Scahill, L., Jeon, S., Boorin, S., McDougle, J.C., Aman, G.M., Dziura, J. (2016). Weight gain and metabolic consequences of risperidone in young children with autism spectrum disorder. Journal of the American Academy of Child and Adolescent Psychiatry, 55(5), 415-23.

Snyder, R., Turgay, A., Aman, M., Binder, C., Fisman, S.

Carroll A. (2002). Effects of risperidone on conduct and disruptive behavior disorders in children with subaverage IQs. Journal of the American Academy of Child and Adolescent Psychiatry, 41(9), 1026-36

Szigethy, E., Wiznitzer, M., Branicky, L.A., Maxwell, K., Findling, R.L. (1999). Risperidone-induced hepatotoxicity in children and adolescents? A chart review study. Journal of Child and Adolescent Psychopharmacology, 9(2), 93-8.

Telles-Correia, D., Barbosa, A., Cortez-Pinto, H. (2017). Psychotropic Drugs and Liver Disease: A Critical Review of Pharmacokinetics and Liver Toxicity. World Journal of Gastrointestinal Pharmacology and Therapeutics, 8(1), 26-38. 
Turgay, A., Binder, C., Snyder, R., Fisman, S. (2002). Longterm safety and efficacy of risperidone for the treatment of disruptive behavior disorders in children with subaverage IQs. Pediatrics, 110(3), 34.

Uchida, H., Pollock, B.G., Bies, R.R. (2009). Predicting ageSpecific dosing of antipsychotics. Clinical Pharmacological Therapy, 86(4), 360-362.
Whitworth, A., Liensberger, D., Fleischhacker, W. (1999). Transient increase of liver enzymes induced by risperidone: Two case reports. Journal of Clinical Psychopharmacology, 19(5), 475-6.

Wright, T., Vandenberg, A. (2007). Risperidone- and quetiapineinduced cholestasis. Annals of Pharmacotherapy, 41(9), 151823. 